\title{
CROSS-BORDER LOAN LIABILITY, THE EXCHANGE RATE AND PROFITABILITY IN THE TURKISH BANKING SECTOR
}

\author{
TÜRKIYE BANKACILIK SEKTÖRÜNDE YURTDIŞI KREDİ \\ YÜKÜMLÜLÜĞÜ, DÖVIZZ KURU VE KÂRLILIK
}

\author{
Gökhan ÖVENÇ* \\ Resul AYDEMİR ${ }^{* *}$
}

\begin{abstract}
We examine how the cross border banking loan liabilities (syndication and securitization loans) and the exchange rate affect the Turkish banking industry profitability using a balanced panel data for the period 2003Q1-2016Q3. We study with different subsamples and model specifications. Overall, we find that the banking sector financial inflows are positively associated with bank profitability. Specifically, the results show that the banking sector cross border inflows have significant and positive impact on return on assets (ROA), return on equity (ROE) and on net interest margin (NIM). The long-term inflows play a more important role than the short-term inflows in explaining profitability in all specifications while short-term inflows have no any significant effect on these profitability indicators. Moreover, we show that the exchange rate has significant and negative impact on ROA and ROE and has insignificant effect on NIM. Our findings are more notable in private banks compared to the whole sample. Given the fact that the existing studies examine the banking profitability through aggregate capital inflows and maturity mismatch, this study will fill a meaningful gap in emerging market literature.
\end{abstract}

Keywords: Cross Border Banking Liability, Long-term Liability, Short-term Liability, The Exchange Rate, Bank Profitability, Net Interest Margin, Return on Asset

JEL Classification: E44, G21, C33

\section{Özet}

2003 1. Çeyrek ile 2016 3. Çeyrek arasındaki dönemi dinamik panel modeliyle incelediğimiz bu çalışmada, yurtdışı bankacılık sektörü kredi yükümlülüğü ile döviz kurunun Türkiye bankacılık sektörü kârlılığını nasıl etkilediğini analiz etmekteyiz. Farklı örneklem ve model spesifikasyonları kullanarak gerçekleştirdiğimiz çalışmada, genel olarak bankacılık sektörü yurtdışı kredi girişleriyle kârlılık

* Assistant Prof., Istanbul University, Faculty of Economics, Department of Economics (English), Beyazit, Fatih, İstanbul, Corresponding Author, gokhanovenc@istanbul.edu.tr, https://orcid.org/0000-0003-4632-9760

** Associate Prof., Istanbul Technical University, Faculty of Management, Department of Economics, Maçka, Beşiktaş, İstanbul, resulaydemir@itu.edu.tr, https://orcid.org/0000-0003-1313-0464 
arasında anlamlı ve pozitif bir ilişki elde ettik. Özellikle, uzun vadeli yurtdışı kredi yükümlülüklerinin kısa vadelilere kıyasla kârlılık göstergeleri üzerinde daha fazla etkiye sahip olduğunu ortaya koyduk. Döviz kuru ve kredi yükümlülükleri değişkenlerini birlikte kullandığımız modelimizde döviz kurunun özsermaye ve aktif kârlılık üzerinde anlamlı ve negatif, net faiz marjı üzerinde ise anlamsız bir etkiye sahip olduğu sonucunu elde ettik. Tüm örneklem ile kıyaslandığında özel bankaların yurtdışı kredi yükümlülüklerinden daha fazla etkilendiği de yaptığımız çalışmanın diğer bir ampirik bulgusudur. Konuyla ilgili mevcut çalışmaların bankacılık sektörü kârlılığını sermaye girişleri ve vade uyumsuzluğu üzerinden incelediklerini düşündügümüzde, bu makale gelişmekte olan ülkeler yazınında anlamlı bir boşluğu dolduracaktır.

Anahtar Kelimeler: Bankacılık Sektörü Yurtdışı Kredi Yükümlülüğü, Uzun Vadeli Kredi Yükümlülüğü, Kısa Vadeli Kredi Yükümlülügüu, Döviz Kuru, Bankacılık Kârlılığı, Net Faiz Marjı, Aktif Kârlılık

JEL Sınıflandırması: E44, G21, C33

\section{Introduction}

The 1990s have witnessed a huge capital inflows from developed regions to emerging market economies in which Latin America, parts of Asia and some Middle Eastern countries have been the center for those capital inflows whose impacts have been mostly observed on current account deficits, monetary expansion, stock market bubbles, exchange rate fluctuations ${ }^{1}$.

As an emerging economy Turkey started to receive first high amount of capital inflows in the late 1980s after converting its economy into fully liberalized market environment in $1980^{2}$. Some important structural economic reforms such as free capital movements, convertibility of the domestic currency, liberalization of loan, deposit rates and foreign exchange regime were implemented during the mid of 1980s and Turkey became a part of global financial system.

Integrated into global financial system has its own advantages as well as risks. As a consequence of liberalized market reforms, the Turkish financial industry and banking service management developed rapidly. The share of the public banks in the sector prominently decreased with the new entrance of the private and foreign banks. Nonetheless, Turkey experienced several crises resulting from domestic and global events. 1991 Gulf War, 1994 Mexico currency crisis, 1997 devaluation, 1997 Far East Financial Crisis, 1998 Russian Crisis, 2000-2001 banking liquidity, FX crises and devaluation ${ }^{3}$. These mixture of domestic and global crises negatively affected Turkish financial and banking industry and then some supervisory and regulatory adjustments have been

1 Calvo, G. and Leiderman, L. and Reinhart, C. M., "Inflows of Capital to Developing Countries in the 1990s" The Journal of Economic Perspectives, Spring, 1996, p. 123-139.

2 Agenor, P. R., and McDermott, C. J., and Üçer, M., "Fiscal imbalances, capital inflows, and the real exchange rate: the case of Turkey" European Economic Review, 1997, 41(3), p. 819-825.

3 Mercan, M. And Reisman, A. and Yolalan, R., and Emel, A. B., "The effect of scale and mode of ownership on the financial performance of the Turkish banking sector: results of a DEA-based analysis", Socio-Economic Planning Sciences, 2003, 37(3), p. 185-188. 
implemented by government and monetary authorities to restructure the banking and financial systems.

Given that capital inflow is predominately intermediated by banking system, the commercial banking industry has an important transmission channel between domestic financial system and international capital flows. Therefore, capital inflows to developing economies are also known to have significant impact on the vulnerability of the financial systems as well as domestic banking industries that is directly related with liquidity boost and domestic credit boom. Turkey has been a significant hub for capital inflows and the weight of the capital inflows in the Turkish economy has increased between 2002 and 2014. For instance, in 2003, the average of the net total financial inflow to real GDP ratio was 0,02 whereas this ratio was 0,17 for the first three quarters of 2014. Although the weight of the financial inflows in Turkish economy has risen since 2002, the volatility of this flow has also hiked. This higher volatility increased concerns related to capital inflows and had a detrimental impact on the stability of financial systems in general and banking industries in particular.

In this context, we examine how banking industry cross-border loan liabilities (the non-core liabilities; as a part of capital inflow) affect the performance of Turkish banks since 2003 . Comprehending the impacts of cross border banking loans on banking profitability is important in the sense that if these inflows have systematic effect on banking profitability, then the volatile, short-run or sudden stop capital inflow may have potential to create a banking crises that increases the financial fragility. To our knowledge, in literature there exists no study focusing on the association between cross-border banking credit inflow and bank profitability. Given the fact that the existing similar studies examine the banking profitability through aggregate capital inflows and maturity mismatch, this study will fill a meaningful gap in emerging market literature.

Specifically, we analyze the effects of banking industry credit inflow on various performance measures of banks such as net interest margin (NIM), return on asset (ROA) and return on equity (ROE). Comparing the impacts of the credit inflow among NIM, ROA and ROE is crucial in the sense that it enables us to observe the dynamics of the banking industry behaviors. For instance, NIM only gives idea about interest income and expenses while ROA has non interest revenue such as fee, trading income, securities and operational costs.

In this study, we firstly use the general banking industry cross border loan liability data and then distinguish between long and short term credit inflows to have much better comprehension about banking profitability. Our estimation results show that banking industry capital inflows (crossborder loan liabilities) are positively associated with bank profitability. Specifically, we find that the credit inflows have significant and positive impact on return on assets (ROA) and return on equity (ROE) while the impact on net interest margin (NIM) is statistically insignificant in the short-run. The long-term cross-border credit inflows play a more important role than the shortterm inflows in explaining profitability in all specifications including NIM. Moreover, we show that the exchange rate has significant and negative impact on banking profitability especially after 
2014, that is directly related with country risk and our findings are more notable in private banks compared to the whole sample. Based on our findings, it can be asserted that monetary authorities of the emerging economies should push the banks to access the long-term credit (cross-border liabilities with long-term maturity) instead of short-term. Also, the introduction of new reserve requirement ratios for banking industry non-deposit FX liabilities by Central Bank of Turkey not only reduce banking liquidity risk ${ }^{44}$ but also increase the banking profitability.

The study is composed of subsequent sections: Section 2 discusses the existing literature on capital inflows and banking. Section 3 shows the model and data. Section 4 presents the econometric methodology. Section 5 interprets the empirical results and Section 6 concludes the article.

\section{Literature Review}

There exists an extensive literature studying the impacts of capital inflows on financial stability in general and banking industry in particular. These studies emphasize the relationship between capital inflows and banking crisis paying special attentions to lending booms, currency crisis or mismatches, current account deficits and intrinsic characteristics of the banking industry and financial liberalization ${ }^{5}$.

In their classical and important study, Calvo and others ${ }^{6}$ briefly examine the capital inflows related problems and emphasize the internal and external factors that drive the capital inflows. While the decrease in international interest rate and rest of the world recession are seen as an external factors, domestic policies such as price stabilization program pushed by fiscal, macroeconomic improvements, institutional reforms and credibility are among the internal factors which directly influence capital inflows. They concludes that mixed domestic policies with higher credibility would transform capital inflows into FDI and reduce the country's risk.

Reinhart and $\mathrm{Calvo}^{7}$ examine the various policies that emerging market economies implement to reduce the damage of the sudden stop in capital flows. They show that emerging market economies have more severe sudden stop problems. In their study dollarization and capital control are two main policies that might reduce the negative impacts of sudden stop in capital inflows.

There is also a big discussion in the literature whether lending boom and banking crisis is associated with financial liberalization and capital inflows. Mishkin ${ }^{88}$ thinks that financial

4 Central Bank of Turkey, Financial Stability Report, November 2015.

5 Caballero, J. A., "Do surges in international capital inflows influence the likelihood of banking crises?", The Economic Journal, October 2014, p.281-290.

6 Calvo, G. and Leiderman, L. and Reinhart, C. M., “The capital inflows problem: Concepts and issues” The Journal of Economic Perspectives, Spring, 1994, 12(3), p. 54-66.

7 Reinhart, C., and Calvo, G., When capital inflows come to a sudden stop: Consequences and policy options, Munich Personal RePEc Archive, 2000, No: 6982.

8 Mishkin, F. S., "Why we shouldn't turn our backs on financial globalization", IMF Staff Papers, 2009, p. 139-145. 
liberalisation fosters lending boom that is raised by capital inflows. Reinhart and Rogoff ${ }^{9}$ also add that surge in capital inflows encourages the banking crisis. In contrast to these views, Mendoza and Terrones ${ }^{1010}$ show that most lending booms are associated with surge in capital flows but not with financial liberalization. Broner and others ${ }^{11}$ also show that during crisis period there appears a high reduction in every type of gross capital flows (direct investments, portfolio, credit).

Based on empirical evidence about the determinants of cross-border bank flows to emerging economies, Hermann and Mihaljek ${ }^{12}$ find that international risk perception and domestic factors significantly affect the foreign borrowing of domestic banks. They show that an increase in global risk-aversion and financial volatility are the two main determinants which reduce the crossborder banking borrowing/lending. Also, they conclude that emerging countries or regions like Eastern Europe, having sound financial and banking systems, are less affected by cross-border loans volatilities compared to developing Latin American or Asian countries.

In his capital inflows, maturity mismatches and banking profitability panel study with emerging economies, Aysun ${ }^{13}$ shows that banking industry maturity mismatches rise during high capital inflows. In his model, Aysun adds that banks are less profitable during crisis periods if they have higher maturity mismatches. Maturity mismatch analysis provides an important ground to notice banking industry balance sheet behaviors in response to changes in capital inflows. Banks may diversify their short and long-term liabilities and assets to gain extra profits when there appears higher capital inflows.

Covering over one hundred countries between 1978-2008, Caballero ${ }^{14}$ finds that surges in net capital flows are associated with systemic banking crises, even in the absence of a credit boom. $\mathrm{He}$ adds that portfolio flows are the ones associated with the highest rise in the likelihood of a crisis compared to FDI and debt flows. This comparison is crucial in order to understand which component of the capital inflows is mostly affecting the banking indicators.

By investigating the relation between global liquidity and cross border banking capital flows, Bruno and Shin ${ }^{15}$ show that banking sector leverage is associated with local currency appreciation

9 Reinhart, C. M., and Rogoff, K., This time is different: eight centuries of financial folly. Princeton University Press, 2009, p. 24-33.

10 Mendoza, E. G., and Terrones, M. E., "An anatomy of credit booms: evidence from macro aggregates and micro data", National Bureau of Economic Research, 2008, No. w14049.

11 Broner, F. and Didier, T. And Erce, A. And Schmukler, S. L., “Gross capital flows: Dynamics and crises”, Journal of Monetary Economics, 2013, 60(1), p. 113-115.

12 Hermann, S. and Mihaljek, D. The determinants of cross-border bank flows to emerging markets: new empirical evidence on the spread of financial crises, Bundesbank Series, 2010, No: 17, p.1-12

13 Aysun, U., "Capital flows, maturity mismatches, and profitability in emerging markets: evidence from bank level data", The Journal of Developing Areas, 2012, 46(1), p. 211-239.

14 Caballero, a.g.m.

15 Bruno, V. and Shin, H. S., "Cross-Border Banking and Global Liquidity ${ }^{\star}$, The Review of Economic Studies, 2014, 82(2), p.539-541. 
through banking sector capital flows which functions like a bridge between exchange rate and financial stability.

In the literature, the relationship between capital inflows and banking industry is mostly analysed over lending boom. The surge in capital inflows transform the commercial banks into large and cheaper credit providers. With banking industry's risk taking and other domestic and international macroeconomic developments, this lending boom may result in banking and financial market distress.

Regarding the Turkish economy and capital flows, most of the studies also emphasize the link between capital flows, lending and current account deficit risk ${ }^{16,17}$. Aysan ${ }^{18}$ et. al, evaluate the new policy tools of the CBRT, interest rate corridor and ROM, that started to be implemented in 2010. These tools were effective to minimize the negative effects of the volatile and short-run capital inflows and support financial stability. Additionally, in the Turkish case, there are some other studies that focus on macroprudential policies that aim to prevent the negative effects of volatile capital inflows ${ }^{19,20}$.

\section{The Model and Data}

We use panel data obtained from the CBRT, TBA ${ }^{2121}$ and TURKSTAT on a quarterly basis between 2003 and 2016. This time period was chosen since Turkish economy had experienced a huge transformation in banking sector regulation after 2001 economic and financial crisis in which accounting standards updated. Therefore the data about banking balance-sheet covering this period is more reliable compared to before 22,23 .

We use quarterly data about 24 banks operating in Turkey including public, private and foreign to cover the Turkish commercial banking industry activities. Three commercial banks are state owned and the rest of them are privately owned commercial banks. Twelve of the private commercial banks in Turkey are owned by foreigners.

16 Yentürk, N., "Short-Term Capital Inflows And Their Impact On Macroeconomic Structure: Turkey In The 1990S", The Developing Economies, 1999, 37(1), 89-113.

17 Alper, K., and Kara, H. And Yörükoğlu, M., Alternative tools to manage capital flow volatility, BIS Paper, 2013, No: (73z).

18 Aysan, A. F. and Fendoglu, S. and Kilinc, M., "Managing short-term capital flows in new central banking: unconventional monetary policy framework in Turkey", Eurasian Economic Review, 2014, 4(1), p.45-69

19 Akçelik, Y. and Basci, E. and Ermisoglu, E., and Oduncu, A., “The Turkish approach to capital flow volatility”, Central Bank of the Republic of Turkey Working Paper, 2013 (06), p.1-8.

20 Alper, K., and Kara, H. And Yörükoğlu, M., a.g.m.

21 The Banks Association of Turkey

22 Aydin, B. and Igan, D., "Bank lending in Turkey: Effects of monetary and fiscal policies", Emerging Markets Finance and Trade, 2012, 48(5), p.78-90.

23 Özsuca, E. A. and Akbostanci, E., An Empirical Analysis of the Risk Taking Channel of Monetary Policy in Turkey. Emerging Markets Finance and Trade, 2015, p.1-10. 
Based on balance-sheet information published quarterly, we gather the details of the assets and liabilities data for each bank, then we calculate net interest margin (NIM), return on equity (ROE), return on asset (ROA), leverage rate, growth rate of real total assets (For summary statistics, see the Table A.1. in the Appendix).

To capture the quarterly capital inflows, we use total net credit under financial inflows and the decomposition of this credit inflow: long and short term inflows to total banking assets ratio.

The models below show our general (1) and detailed (2) model specifications.

$$
\begin{aligned}
& y_{i t}=\alpha y_{i, t-1}+\beta^{/} X_{i t}+\gamma^{/} M_{\mathrm{t}}+\varepsilon_{i t} \quad ; \quad \varepsilon_{i t}=\eta_{i}+v_{i t} \\
& \mathrm{Y}_{\mathrm{it}}=\beta_{1} \mathrm{Y}_{\mathrm{i}, \mathrm{t}-1}+\beta_{2} L \text { Lev }_{\mathrm{it}}+\beta_{3} \text { LAsset }_{\mathrm{it}}+\beta_{4} L \text { Gdp }_{\mathrm{t}}+\beta_{5} \text { LLongInf }_{\mathrm{t}}+ \\
& \beta_{6} \text { LShortInf }_{\mathrm{t}}+\beta_{7} L \mathrm{FX}+\beta_{8} L H H I+ \\
& \varepsilon_{\mathrm{it}}
\end{aligned}
$$

In the model, $y_{i t}$ refers to dependent variable and $y_{i, t-1}$ is lagged value of the dependent variable. $X_{\text {it }}$ is the bank-specific variables matrice and $M_{t}$ is the financial inflows and macroeconomic variables matrice. $\eta_{i}$ is a bank individual effect, and $v_{i t}$ refers to an idiosyncratic disturbance.

Although our main focus is to see the effects of total credit inflows and types of credit inflows on banking profitability, we can observe the impacts of bank-specific and macroeconomic variables with dynamic panel data in which the lag of dependent variable is used. Using the lag of dependent variable into dynamic model enables us to discover significant relationship by using appropriate instrumental variables and technique.

In our model specification, firstly we use net interest margin NIM ((interest income-interest expense)/total assets) as a dependent variable. We include (Lev) Leverage (debt (liabilities-equity) to total asset ratio) and (Asset) Assetgrowth (growth rate of real total assets by obtaining net rise or fall of the total assets compared to previous period total assets) into bank-specific variables matrice. These two bank-specific variables might enable us to discover the possible effects of the balance sheet structure on banking performances. Under macroeconomic variable matrices, we use quarterly real GDP growth rate $(G d p)$, banking sector credit inflows to total assets ratios and divide them into two category; short and long-term inflows (LongInf and ShortInf). We also employ the exchange rate $(F X)$ variable in some model specifications to control the country risk since domestic banking industry borrow and pay this loan liability back in foreign currency.

Additionally, we calculate Herfindahl-Hirschman Index $(H H I)$ to measure the impact of competitiveness among banking industry under macroeconomic variables matrice ${ }^{24}$. As instrumental variables, we use liquidity ratio by calculating liquid assets to debt ratio and capital adequacy ratio. 
We apply the same procedure for return on assets and return on equity as dependent variables to compare the results with NIM. It is possible for banks to have higher non-interest income than interest income that might reduce or cancel out the net effect of the financial inflows on net profitability through trading income and hedging. Therefore, this comparision is crucial in terms of realizing the net effect of financial inflows on net banking profitability apart from net interest margin (NIM).

Normally, we expect a positive relationship between growth rate of total assets and bank profitability since main source of the loans that banks lend is assets. The expected effect of the leverage rate on profitability is negative. The leverage rate may increase due to two reasons: the debt may rise or total assets may fall. Therefore, increase in debt limits bank's opportunity to lend money and therefore profitability. But, this association might change based on which variable used as a dependent one since higher leverage rate means that lower equity or asset which may have different impact on ROA and ROE.

The expected impact of the total credit inflows on banking profitability is positive since in the literature there exists close positive relationship between capital inflows and lending. Therefore, we expect that banking profitability increases through lending channels. However, the different types of credit inflows such as long-term or short-term might have different impacts on net banking profitability measures and this may create an ambiguity between inflows and banking performances.

\section{Empirical Methodology}

To estimate the dynamic panel data model with fixed effects specified as equation (1), we use a quarterly data set of a balanced panel of Turkish commercial banks for the period 2003Q1 -2014Q3. The composite error term in a dynamic panel data model such as (1), is associated with the lagged dependent variable even if the error term is not serially correlated ${ }^{2525}$. The individual effects of the model are removed by the within transformation and this technique produces inconsistent estimates since the correlation still exists. As time dimension goes to infinity, within transformation estimator produce consistent estimation for the coefficents related with lagged dependent variable and independent variables. In literature, the dynamic panel GMM estimator by Arellano and Bond ${ }^{2626}$ have been mostly used to estimate this kind of model. But when the number of moment conditions is large and the instruments are weak, dynamic panel GMM would produce obvious biased estimates ${ }^{27}$. When time dimension gets larger, compared to dynamic panel GMM within transformation estimator is consistent.

Endogeneity problem in independent variables is the another significant assumption that within estimator requires. Therefore, Davidson-MacKinnon exogeneity test is conducted and it is found

25 Baltagi, B. H., "Forecasting with Panel Data" Journal of Forecasting, 2008, 27, p. 153-173.

26 Arellano, M. and Bond, S., "Some tests of specification for panel data: Monte Carlo evidence and an application to employment equations", The review of economic studies, 1991, 58(2), p. 277-297.

27 Baltagi, a.g.m. 
that there is no any endogeneity problem except the lagged dependent variable ${ }^{28}$. Additionally, we carry heteroscedasticity ${ }^{29}$ and autocorrelation ${ }^{30}$ tests. The result of these two tests can be seen at the bottom of table results of model.

Since endogeneity of the independent variables with non-spherical errors makes the within estimator to be inconsistent and inefficient, we use the GMM fixed effect estimator to consider these issues. Fixed effects GMM method is different than system ${ }^{31}$ and two-step difference GMM ${ }^{32}$ methods in two manners. First of all, it takes care of heteroscedasticity and autocorrelation and therefore would produce more efficient estimates ${ }^{33}$. Secondly, the number of IVs does not vary with time periods (it does not use dynamic IV). Therefore, when T becomes larger, the weak IVs problem stated above can be eliminated.

In this study, we employ the lagged values of the lagged dependent variable and the current and lagged values of the explanatory variables as instruments. The validity of instruments employed in the model is checked by three tests: Kleibergen and Paap rank LM test ${ }^{34}$, Cragg-Donald F test $^{35}$ and Hansen J statistic ${ }^{36}$. Kleibergen and Paap rank LM and Cragg-Donald F tests check whether instruments are associated with IVs while Hansen J statistic tests whether IVs are related with errors. When testing the validity of instruments, the non-spherical features of errors are allowed since these tests are robust to non-spherical disturbances. The result of these three tests can be seen at the bottom of table results of model. Kleibergen and Paap rank LM and CraggDonald F tests results show that the IVs are not serially correlated with lagged value of dependent variable. Therefore, IVs used in these models seem to have valid features. Additionally, time series properties of the variables used in this study are tested. HHI variable has only unit root problem and hence we only employ first difference of HHI and use the level of all other variables to estimate the model. We do not perform the cross-section dependency test since our panel model includes banking sector data within a country, Turkey, in which different banks are being affected by each other. Therefore, we assume that our data has cross-section dependency and apply the second generation unit root test.

28 Davidson, R. and MacKinnon, J.G., Estimation and Inference in Econometrics. Oxford:Oxford University Press, 1993.

29 Greene, W. H., Econometric Analysis. Granite Hill Publishers, 2008.

30 Wooldridge, J. M., Econometric analysis of cross section and panel data. MIT press, 2010.

31 Blundell, R.W. and Bond, S.R., "Initial Conditions and Moment Restrictions in Dynamic Panel Data Models", Journal of Econometrics, 1998,87, p. 115-143.

32 Arellano, M. and Bond, S., a.g.m.

33 Schaffer, M. E., “xtivreg2: Stata module to perform extended IV/2SLS, GMM and AC/HAC, LIML and k-class regression for panel data models", Statistical Software Components, 2012.

34 Kleibergen, F. and Paap, R., "Generalized reduced rank tests using the singular value decomposition", Journal of econometrics, 2006, 133(1), p. 97-126.

35 Cragg, J. G., and Donald, S.G., “Testing identifiability and Specification in Instrumental Variables Models”, Econometric Theory, 1993, 9, p.222-240.

36 Hansen, L. P., "Large sample properties of generalized method of moments estimators", Econometrica: Journal of the Econometric Society, 1982, p. 1029-1054. 


\section{Estimation Results}

In this part, based on our econometric model results, the impacts of the financial inflows on Turkish banking profitability and the details of these impacts will be interpreted. We present the estimation results in Table A.2. ,Table A.3. and Table A.4. in the Appendix . Since our main focus is to see the effects of credit inflows on banking profitability, other significant explanatory variables that are bank-specific will be mentioned briefly. As seen from Table A.4.2, the lag of the dependent variable, lnim, contributes positively to net interest margin as expected. One unit increase in lnim would raise net interest margin by 0,80 unit. The lag of ROE also significantly affects the ROE as well as there exists high association between the ROA and its lag variable. Based on our estimation results, net interest margin is being more affected by its previous value not only in terms of significance level but also the magnitude of the coefficient that lnim has. It can be inferred that interest incomes and interest expenses of the banking industry has more lag dependency compared to general profitability.

We don't find any significant relationships between bank-specific variables and ROA and ROE in all specifications under $10 \%$ significance level. However, leverage rate and growth rate of total assets significantly and negatively affect the NIM which means that the banking industry can not increase their interest income to the same degree that total assets grow. Note that, growth rate of total asset positively influences the ROA and ROE but it is statistically significant under \% 15 level.

Regarding the banking industry credit inflows types, Table A.4.3 shows the details of the estimation results. The lag value of the total banking-industry cross-border credit inflow to total asset ratio has significant and positive impact on both ROA and ROE while insignificant impact on NIM. For instance, one unit rise in credit inflow is associated with 0.25 unit increase in ROE under 5\% significant level. When we decompose the total banking-industry cross-border credit inflows into two category: long and short-term, the relationship between inflows and banking profitability measures become more severe.

The long-term banking industry credit inflow positively and significantly affect the all three banking profitability measures while there is no any significant relationship between short-term inflow and NIM, ROA and ROE. For instance, one unit increase in long-term credit inflow has significant and positive influence on ROE by 0,42 unit, on ROA by 0.098 unit and on NIM by 0.031 unit. ROE is more affected by the long-term credit inflow compared to ROA and NIM. ROA has been influenced by long-term credit inflow about 3 times more than NIM. These associations show that long-term credit inflow enlarges the banking industry interest and non-interest income capacity. Also, this result indicates that ROE is more sensitive to the inflows.

Credit inflow creates a pressure on banking profitability through the expenses since banks pay interest expenses for their foreign borrowing and this dominates the general profitability and interest income in the short-run. However, this foreign credit borrowing can be transformed into interest and non-interest income through domestic lending or trading transactions in the 
long-run. That is why, it is observed positive and significant association between long-term inflow and NIM, ROA and ROE.

Additionally, we observe higher positive relationship between private banking profitability measures and credit inflows compared to whole sample since public banks are less dependent on the foreign financial sources and on average public banks have higher deposit than private banks that decrease their tendency towards foreign borrowing.

The impacts of the financial flows on banking profitability might change during the negative economic growth periods. Therefore, we introduce a GDP growth rate dummy (1 whenever quarterly GDP growth rate is negative; 0 otherwise) to control the effect of economic cycles on profitability measures and find that this GDP dummy has no significant impact in all dependent variables. Also, we generate an interaction term by multiplying the dummy with the credit inflows to observe the impact of the inflow on the inflow coefficient during the negative growth period and do not find any significant association.

Since credit inflows are form of liquid assets, profit motivation of the banking especially private banking industry dominates the negative effect of the credit inflows and transform the inflows into income-generated transactions. For instance, in our sample we observe higher correlation between liquid assets and long-term credit inflows compared to short-term inflows.

Banking industry should borrow long-term credit to have higher profitability. Long-term inflows is also desirable for the financial system's well being in which short-term inflows can damage the banking debt to asset ratio. Based on our results, it can be inferred that banks prefer to have longterm borrowing that affects all performances positively. So why they have short-term borrowing?

Banks may have to borrow short from the abroad when they are not able to borrow long. For instance, during the 2008 financial crises period, long-term credit inflow to asset ratio decreased while the short-term inflow increased dramatically. Therefore, borrowing structure is directly related with the global and domestic macroeconomic, financial conditions and risks. As seen in our results, even banks have short-term borrowing from abroad, they are able to generate noninterest income.

Based on our model including the exchange rate variable (FX), we find that there exists negative and significant association between the FX and ROA and ROE while this association turns out to be insignificant between FX and NIM. For instance, one unit increase in the exchange rate has significant and negative influence on ROE by 0,023 unit, on ROA by 0.006 unit. ROE and ROA are significantly affected by the FX compared to NIM. These associations show that FX limits the banking industry non-interest income capacity which is consistent since any rise in FX during the borrowing period increase the cost of the banking sector loan liability. Interestingly, our findings are more notable in private banks compared to the whole sample ${ }^{37}$. When we exclude public banks from our whole sample, we find that the relationships between cross border loan

37 The estimation result of this subsample is not included due to the many estimation tables. 
liability and profitability are more notable. This is not an unexpected result since public banks in Turkey have more access to domestic deposits which reduce their reliance on non-core liability (cross-border loan).

Based on our findings, it can be asserted that monetary authorities of the emerging economies should push the banks to access the long-term credit (cross-border liabilities with long-term maturity) instead of short-term. Also, the introduction of new reserve requirement ratios for banking industry non-deposit FX liabilities by Central Bank of Turkey not only reduce banking liquidity risk ${ }^{38}$ but also increase the banking profitability.

\section{Conclusion}

We examine how the cross-border banking loan inflows and the exchange rate affect banking profitability in Turkish economy using a balanced panel data for the period 2003Q1-2016Q3 by applying the fixed effect GMM technique. We employ three different dependent variables: net interest margin, return on assets and return on equity to see the possible impacts of these crossborder loan liabilities and the exchange rate.

In general, overall outlook of Turkish banking industry performance seems that it is positively influenced by cross-border credit inflows. The types of credit inflows appear to have different impacts on profitability. Our estimation results show that long-term banking industry credit inflow generates more non-interest income compared to interest income while the short-term credit inflows have no significant effect on general profitability. Additionally, long-term credit inflow has more impact on ROE than on ROA and NIM. Also, we show that the exchange rate has significant and negative impact on ROA and ROE and has insignificant effect on NIM. Our findings are more notable in private banks compared to the whole sample.

Moreover, we try various measures to control economic fluctuations and find that negative economic growth dummy and interaction term have no extra significant effect in all dependent variables. As a future study, it would be interesting to conduct a cross-country analysis of the effects of cross border banking inflows on bank profits in the emerging markets. Also, combining this study with interest rate and banking lending enable us to have wider comprehension about the link between monetary policy and bank profits in emerging markets context. 


\section{Appendix}

Table A. I: Summary Statistics Based on Full Sample Period

\begin{tabular}{|llllll|}
\hline Variables & Formula & Mean & $\begin{array}{l}\text { Std. } \\
\text { Dev. }\end{array}$ & Min & Max \\
\hline NIM & (Interest Income-Interest Expense)/Total Assets & 0.0281 & 0.0248 & -0.2169 & 0.2395 \\
ROA & Net Profit After Tax/Total Assets & 0.0073 & 0.0314 & -0.6320 & 0.2202 \\
ROE & Net Profit After Tax/Equity & 0.0663 & 0.1082 & -1.7863 & 0.4645 \\
LevRate & Debt/Total Assets & 0.8360 & 0.1563 & 0.0839 & 0.9597 \\
GrowthAsset & Change in Real Total Assets compared to previous & 0.0592 & 0.1500 & -0.6214 & 1.6813 \\
& quarter & & & & \\
GDPgrowth & Real GDP growth rate with respect to previous & 0.0482 & 0.0482 & -0.1482 & 0.1258 \\
& quarter & & & & \\
CreditInf & Cumulative Banking Sector Credit Inflow/ & 0.0920 & 0.0237 & 0.0526 & 0.0143 \\
& Cumulative Total Assets & & & & \\
LongCreditInf & Cumulative Banking Sector Credit LongTterm & 0.0570 & 0.0221 & 0.0179 & 0.1093 \\
& Inflow/Cumulative Total Assets & & & & \\
ShortCreditInf & Cumulative Banking Sector Credit Short-Term & 0.0350 & 0.0145 & 0.0084 & 0.0581 \\
FX & Inflow/Cumulative Total Assets & 1.7340 & 0.4871 & 1.1875 & 2.9630 \\
HHI & The Exchange Rate (US Dollar to Turkish Lira) & 0.1061 & 0.0084 & 0.0955 & 0.1260 \\
\hline
\end{tabular}

Notes: Variables: NIM (Net Interest Margin), ROA (Return on Asset), ROE (Return on Equity), LevRate (Leverage Rate), GrowthAsset (Growth Rate of Real Total Assets), GDPgrowth (Real GDP growth rate compared to previous quarter), CreditInf (Banking industry credit inflow/total banking assets), LongCreditInf (Long-term CreditInf), ShortCreditInf (Short-term CreditInf), FX (US Dollar to Turkish Lira Exchange Rate), HHI (Herfindahl-Hirschman Index).

Table A.2 :Estimation Results-Banking Credit Inflow-2003QI-20I4Q3

\begin{tabular}{|c|c|c|c|c|c|}
\hline \multirow[b]{2}{*}{$\begin{array}{l}\text { Explanatory } \\
\text { Variables }\end{array}$} & \multicolumn{2}{|l|}{ ROE } & \multicolumn{2}{|l|}{ ROA } & \multirow[t]{2}{*}{ NIM } \\
\hline & Coefficients & $\begin{array}{l}\text { Explanatory } \\
\text { Variables }\end{array}$ & Coefficients & $\begin{array}{l}\text { Explanatory } \\
\text { Variables }\end{array}$ & \\
\hline LROE & $\begin{array}{l}0.6648^{* * *} \\
(0.000)\end{array}$ & LROA & $\begin{array}{l}0.6378^{* * *} \\
(0.000)\end{array}$ & LNIM & $\begin{array}{l}0.7986^{* * *} \\
(0.000)\end{array}$ \\
\hline LLeverage & $\begin{array}{l}-9.55 e-10 \\
(0.221)\end{array}$ & LLeverage & $\begin{array}{l}5.01 \mathrm{e}-11 \\
(0.668)\end{array}$ & LLeverage & $\begin{array}{l}-5.95 e-10^{* * *} \\
(0.000)\end{array}$ \\
\hline LAssetgrowth & $\begin{array}{l}0.0047 \\
(0.664)\end{array}$ & LAssetgrowth & $\begin{array}{l}0.0046 \\
(0.155)\end{array}$ & LAssetgrowth & $\begin{array}{l}-0.0077^{\star *} \\
(0.050)\end{array}$ \\
\hline GDPgrowth & $\begin{array}{l}-0.0084 \\
(0.716)\end{array}$ & GDPgrowth & $\begin{array}{l}-0.0051 \\
(0.189)\end{array}$ & GDPgrowth & $\begin{array}{l}0.0016 \\
(0.317)\end{array}$ \\
\hline CreditInf & $\begin{array}{l}0.1235^{\star} \\
(0.065)\end{array}$ & CreditInf & $\begin{array}{l}0.0414^{\star *} \\
(0.041)\end{array}$ & CreditInf & $\begin{array}{l}-0.0038 \\
(0.700)\end{array}$ \\
\hline HHI & $\begin{array}{l}-0.9388 \\
(0.341)\end{array}$ & HHI & $\begin{array}{l}0.3403 \\
(0.206)\end{array}$ & HHI & $\begin{array}{l}0.1649 \\
(0.247)\end{array}$ \\
\hline
\end{tabular}




\begin{tabular}{|c|c|c|c|c|c|}
\hline Rank LM & $\begin{array}{l}9.206^{\star *} \\
(0.026)\end{array}$ & Rank LM & $\begin{array}{l}9.002^{\star \star} \\
(0.029)\end{array}$ & Rank LM & $\begin{array}{l}18.162^{\star * *} \\
(0.001)\end{array}$ \\
\hline Cragg-Donald & $21.484^{\star * *}$ & Cragg-Donald & $77.276^{\star * *}$ & Cragg-Donald & $139.034^{* * *}$ \\
\hline Hansen & $\begin{array}{l}3.271 \\
(0.194)\end{array}$ & Hansen & $\begin{array}{l}0.963 \\
(0.617)\end{array}$ & Hansen & $\begin{array}{l}1.912 \\
(0.590)\end{array}$ \\
\hline $\mathbf{F}$ & $\begin{array}{l}3.04^{* * *} \\
(0.006)\end{array}$ & F & $\begin{array}{l}3.640^{\star * *} \\
(0.001)\end{array}$ & F & $\begin{array}{l}23.27^{\star * *} \\
(0.000)\end{array}$ \\
\hline Fm & $\begin{array}{l}4.78^{\star * *} \\
(0.000)\end{array}$ & Fm & $\begin{array}{l}2.44^{*} \\
(0.000)\end{array}$ & Fm & $\begin{array}{l}4.02^{\star * *} \\
(0.000)\end{array}$ \\
\hline $\mathbf{L M}_{\mathrm{HEC}}$ & $\begin{array}{l}7665.92^{* * *} \\
(0.000)\end{array}$ & $\mathrm{LM}_{\mathrm{HEC}}$ & $\begin{array}{l}75685.66^{* * *} \\
(0.000)\end{array}$ & $\mathbf{L M}_{\mathrm{HEC}}$ & $\begin{array}{l}15821.32^{* * *} \\
(0.000)\end{array}$ \\
\hline $\mathbf{F}_{\mathrm{AC}}$ & $\begin{array}{l}78.431^{* * *} \\
(0.000)\end{array}$ & $\mathbf{F}_{\mathrm{AC}}$ & $\begin{array}{l}1041.083^{* * *} \\
(0.000)\end{array}$ & $\mathbf{F}_{\mathrm{AC}}$ & $\begin{array}{l}37.078^{* * *} \\
(0.000)\end{array}$ \\
\hline
\end{tabular}

Notes: ${ }^{* *}$ (significant at $\% 1$ level); ${ }^{* *}$ (significant at $\% 5$ level); ${ }^{*}$ (significant at $\% 1$ level). The numbers in parantheses show the P-values. Variables: NIM (Net Interest Margin), LNIM (the lag of NIM), ROA (Return on Assets), LROA (the lag of ROA), ROE (Return on Equity) LROE (the lag of ROE), LLeverage (the lag of Leverage rate), LAssetgrowth (the lag of growth rate of real total assets), GDPgrowth (Real GDP growth rate), CreditInf (Banking industry credit inflow/ total assets), HHI (Herfindahl Hirschman Index) . F statistic tests for overall significance of the model. Fm statistic tests for absence of individual effetcs. $\mathrm{LM}_{\text {het }}$ and $\mathrm{F}_{\mathrm{AC}}$ statistics test for homoscedasticity and absence of serial correlation. Rank LM, Cragg-Donald, Hansen statistics are tests for the validity of instruments. Kleibergen and Paap rank LM and CraggDonald F tests check whether instruments are associated with IVs while Hansen J statistic tests whether IVs are related with errors. . Kleibergen and Paap rank LM and Cragg-Donald F tests results show that the IVs are not serially correlated with lagged value of dependent variable. Therefore, IVs used in these models seem to have valid features. For the critical values of Cragg-Donald Test please look at Stock and Yogo (2002) paper.

Table A.3 : Estimation Results-Banking Credit Inflow (Long and Short-Term)

\begin{tabular}{|c|c|c|c|c|c|}
\hline $\begin{array}{l}\text { Explanatory } \\
\text { Variables }\end{array}$ & $\begin{array}{l}\text { NIM } \\
\text { Coefficients }\end{array}$ & $\begin{array}{l}\text { Explanatory } \\
\text { Variables }\end{array}$ & $\begin{array}{l}\text { ROE } \\
\text { Coefficients }\end{array}$ & $\begin{array}{l}\text { Explanatory } \\
\text { Variables }\end{array}$ & $\begin{array}{l}\text { ROA } \\
\text { Coefficients }\end{array}$ \\
\hline LNIM & $\begin{array}{l}0.8008^{\star * \star} \\
(0.000)\end{array}$ & LROE & $\begin{array}{l}0.6383^{* * *} \\
(0.000)\end{array}$ & LROA & $\begin{array}{l}0.6301^{* * *} \\
(0.000)\end{array}$ \\
\hline LLeverage & $\begin{array}{l}-6.23 \mathrm{E}-10^{\star * *} \\
(0.000)\end{array}$ & LLeverage & $\begin{array}{l}-1.23 \mathrm{E}-09 \\
(0.148)\end{array}$ & LLeverage & $\begin{array}{l}1.10 \mathrm{E}-11 \\
(0.930)\end{array}$ \\
\hline LAssetgrowth & $\begin{array}{l}-0.0076^{\star *} \\
(0.058)\end{array}$ & LAssetgrowth & $\begin{array}{l}0.0051 \\
(0.632)\end{array}$ & LAssetgrowth & $\begin{array}{l}0.0050 \\
(0.122)\end{array}$ \\
\hline GDPgrowth & $\begin{array}{l}0.0013 \\
(0.426)\end{array}$ & GDPgrowth & $\begin{array}{l}-0.0079 \\
(0.719)\end{array}$ & GDPgrowth & $\begin{array}{l}-0.0058 \\
(0.158)\end{array}$ \\
\hline LongInf & $\begin{array}{l}0.0316^{*} \\
(0.086)\end{array}$ & LongInf & $\begin{array}{l}0.4226^{* *} \\
(0.013)\end{array}$ & LongInf & $\begin{array}{l}0.0982^{* *} \\
(0.023)\end{array}$ \\
\hline ShortInf & $\begin{array}{l}0.0073 \\
(0.486)\end{array}$ & ShortInf & $\begin{array}{l}0.1712 \\
(0.191)\end{array}$ & ShortInf & $\begin{array}{l}0.0357 \\
(0.242)\end{array}$ \\
\hline HHI & $\begin{array}{l}0.0761^{* *} \\
(0.012)\end{array}$ & HHI & $\begin{array}{l}0.5773 \\
(0.170) \\
\end{array}$ & HHI & $\begin{array}{l}0.0844 \\
(0.377) \\
\end{array}$ \\
\hline Rank LM & $17.834^{\star * *}$ & Rank LM & $9.337^{\star *}$ & Rank LM & $9.134^{* *}$ \\
\hline
\end{tabular}




\begin{tabular}{|c|c|c|c|c|c|}
\hline & $(0.001)$ & & $(0.025)$ & & $(0.027)$ \\
\hline Cragg-Donald & $137.270^{\star * *}$ & Cragg-Donald & $19.763^{* * *}$ & Cragg-Donald & $73.494^{\star * *}$ \\
\hline Hansen & $\begin{array}{l}2.016 \\
(0.569)\end{array}$ & Hansen & $\begin{array}{l}3.080 \\
(0.214)\end{array}$ & Hansen & $\begin{array}{l}0.898 \\
(0.638)\end{array}$ \\
\hline F & $\begin{array}{l}38.45^{* * *} \\
(0.006)\end{array}$ & F & $\begin{array}{l}7.80^{* * *} \\
(0.000)\end{array}$ & $\mathrm{F}$ & $\begin{array}{l}4.18^{\star * *} \\
(0.001)\end{array}$ \\
\hline Fm & $\begin{array}{l}20.73^{* * *} \\
(0.000)\end{array}$ & $\mathrm{Fm}$ & $\begin{array}{l}10.28^{\star * *} \\
(0.000)\end{array}$ & Fm & $\begin{array}{l}7.28^{* * *} \\
(0.000)\end{array}$ \\
\hline $\mathbf{L M}_{\mathrm{HEC}}$ & $\begin{array}{l}23005.74^{* * *} \\
(0.000)\end{array}$ & $\mathrm{LM}_{\mathrm{HEC}}$ & $\begin{array}{l}10301.45^{* * *} \\
(0.000)\end{array}$ & $\mathrm{LM}_{\mathrm{HEC}}$ & $\begin{array}{l}1.30 \mathrm{E}+05^{\star * *} \\
(0.000)\end{array}$ \\
\hline $\mathrm{F}_{\mathrm{AC}}$ & $\begin{array}{l}3.306^{*} \\
(0.082)\end{array}$ & $\mathrm{F}_{\mathrm{AC}}$ & $\begin{array}{l}5.227^{* *} \\
(0.031)\end{array}$ & $\mathrm{F}_{\mathrm{AC}}$ & $\begin{array}{l}38.546^{* * *} \\
(0.000)\end{array}$ \\
\hline
\end{tabular}

Notes: ${ }^{* *}$ (significant at $\% 1$ level); ${ }^{* *}\left(\right.$ significant at $\% 5$ level); ${ }^{\star}$ (significant at $\% 1$ level). The numbers in parantheses show the P-values. Variables: NIM (Net Interest Margin), LNIM (the lag of NIM), ROA (Return on Assets), LROA (the lag of ROA), ROE (Return on Equity) LROE (the lag of ROE), LLeverage (the lag of Leverage rate), LAssetgrowth (the lag of growth rate of real total assets), GDPgrowth (Real GDP growth rate), LongInf (Banking industry long-term credit inflow/total assets), ShortInf (Banking industry short-term credit inflow/total assets), HHI (The first difference of Herfindahl Hirschman Index) . F statistic tests for overall significance of the model. Fm statistic tests for absence of individual effetcs. $\mathrm{LM}_{\text {het }}$ and $\mathrm{F}_{\mathrm{AC}}$ statistics test for homoscedasticity and absence of serial correlation. Rank LM, CraggDonald, Hansen statistics are tests for the validity of instruments. Kleibergen and Paap rank LM and Cragg-Donald F tests check whether instruments are associated with IVs while Hansen J statistic tests whether IVs are related with errors. . Kleibergen and Paap rank LM and Cragg-Donald F tests results show that the IVs are not serially correlated with lagged value of dependent variable. Therefore, IVs used in these models seem to have valid features. For the critical values of Cragg-Donald Test please look at Stock and Yogo (2002) paper.

Table A.4 : Estimation Results-Full Sample with the Exchange Rate ${ }^{39}$

\begin{tabular}{|c|c|c|c|c|c|}
\hline \multirow[t]{2}{*}{$\begin{array}{l}\text { Explanatory } \\
\text { Variables }\end{array}$} & NIM & $\begin{array}{l}\text { Explanatory } \\
\text { Variables }\end{array}$ & ROE & $\begin{array}{l}\text { Explanatory } \\
\text { Variables }\end{array}$ & \multirow{2}{*}{$\begin{array}{l}\text { ROA } \\
\text { Coefficients }\end{array}$} \\
\hline & Coefficients & & Coefficients & & \\
\hline LNIM & $\begin{array}{l}0.7146^{\star * *} \\
(0.000)\end{array}$ & LROE & $\begin{array}{l}0.4567^{\star * \star} \\
(0.004)\end{array}$ & LROA & $\begin{array}{l}0.48002^{\star * *} \\
(0.053)\end{array}$ \\
\hline LLeverage & $\begin{array}{l}-0.0100 \\
(0.696)\end{array}$ & LLeverage & $\begin{array}{l}0.1113 \\
(0.400)\end{array}$ & LLeverage & $\begin{array}{l}-0.0498 \\
(0.439)\end{array}$ \\
\hline LAssetgrowth & $\begin{array}{l}0.0267^{\star \star} \\
(0.012)\end{array}$ & LAssetgrowth & $\begin{array}{l}0.0219^{* *} \\
(0.316)\end{array}$ & LAssetgrowth & $\begin{array}{l}0.02319^{* *} \\
(0.010)\end{array}$ \\
\hline GDPgrowth & $\begin{array}{l}0.09483^{\star * *} \\
(0.000)\end{array}$ & GDPgrowth & $\begin{array}{l}0.2058^{\star \star *} \\
(0.000)\end{array}$ & GDPgrowth & $\begin{array}{l}0.0204^{\star *} \\
(0.016)\end{array}$ \\
\hline LongInf & $\begin{array}{l}0.0807 \\
(0.155)\end{array}$ & LongInf & $\begin{array}{l}0.5142 \\
(0.135)\end{array}$ & LongInf & $\begin{array}{l}0.1906^{\star *} \\
(0.043)\end{array}$ \\
\hline ShortInf & $\begin{array}{l}0.0135 \\
(0.811)\end{array}$ & ShortInf & $\begin{array}{l}-0.0184 \\
(0.961)\end{array}$ & ShortInf & $\begin{array}{l}0.0560 \\
(0.442)\end{array}$ \\
\hline
\end{tabular}

39 Important Note: This estimation result covers the period between 2003Q1 and 2016Q3. The period after 2013 is critical in the sense that the Turkish banking sector began to rely more on cross border loan liability since its loan to domestic deposit ratio exceeded the critical level one. Also, the exchange rate, that was nearly stable during 2003 and 2014, started to increase stemming from domestic and international risks along with FED's policy decision. 


\begin{tabular}{|c|c|c|c|c|c|}
\hline HHI & $\begin{array}{l}-0.0022 \\
(0.303) \\
-0.0758 \\
(0.415)\end{array}$ & HHI & $\begin{array}{l}-0.023^{* *} \\
(0.047) \\
-0.0083 \\
(0.989)\end{array}$ & HHI & $\begin{array}{l}-0.0064^{* *} \\
(0.050) \\
-0.1245 \\
(0.290)\end{array}$ \\
\hline Rank LM & $\begin{array}{l}30.598^{\star * *} \\
(0.000)\end{array}$ & Rank LM & $\begin{array}{l}7.071^{\star *} \\
(0.029)\end{array}$ & Rank LM & $\begin{array}{l}5.047^{\star} \\
(0.0802)\end{array}$ \\
\hline Cragg-Donald & $66.554^{* * *}$ & Cragg-Donald & $94.175^{* * *}$ & Cragg-Donald & $328.281^{* * *}$ \\
\hline Hansen & $\begin{array}{l}12.695 \\
(0.0018)\end{array}$ & Hansen & $\begin{array}{l}3.077 \\
(0.079)\end{array}$ & Hansen & $\begin{array}{l}1.238 \\
(0.265)\end{array}$ \\
\hline F & $\begin{array}{l}74.18^{* * *} \\
(0.000)\end{array}$ & $\mathrm{F}$ & $\begin{array}{l}28.40^{* * *} \\
(0.000)\end{array}$ & $\mathrm{F}$ & $\begin{array}{l}11.54^{* * *} \\
(0.000)\end{array}$ \\
\hline Fm & $\begin{array}{l}12.66^{\star * *} \\
(0.000)\end{array}$ & Fm & $\begin{array}{l}12.25^{\star \star *} \\
(0.000)\end{array}$ & Fm & $\begin{array}{l}6.04^{* * *} \\
(0.000)\end{array}$ \\
\hline $\mathbf{L M}_{\mathrm{HEC}}$ & $\begin{array}{l}8163.48^{* * *} \\
(0.000)\end{array}$ & $\mathbf{L M}_{\mathrm{HEC}}$ & $\begin{array}{l}2.8 \mathrm{e}+05^{* * *} \\
(0.000)\end{array}$ & $\mathbf{L M}_{\mathrm{HEC}}$ & $\begin{array}{l}2.8 \mathrm{e}+05^{* * *} \\
(0.000)\end{array}$ \\
\hline $\mathbf{F}_{\mathrm{AC}}$ & 5.859 & $F_{A C}$ & 21.152 & $\mathrm{~F}_{\mathrm{AC}}$ & $255.117^{\star}$ \\
\hline
\end{tabular}

Notes: ${ }^{* *}$ (significant at \% 1 level); ${ }^{* *}$ (significant at $\% 5$ level); ${ }^{*}$ (significant at \% 1 level). The numbers in parantheses show the P-values. Variables: NIM (Net Interest Margin), LNIM (the lag of NIM), ROA (Return on Assets), LROA (the lag of ROA), ROE (Return on Equity) LROE (the lag of ROE), LLeverage (the lag of Leverage rate), LAssetgrowth (the lag of growth rate of real total assets), GDPgrowth (Real GDP growth rate), LongInf (Banking industry long-term credit inflow/total assets), ShortInf (Banking industry short-term credit inflow/total assets), HHI (The first difference of Herfindahl Hirschman Index) . F statistic tests for overall significance of the model. Fm statistic tests for absence of individual effetcs. $\mathrm{LM}_{\text {het }}$ and $\mathrm{F}_{\mathrm{AC}}$ statistics test for homoscedasticity and absence of serial correlation. Rank LM, CraggDonald, Hansen statistics are tests for the validity of instruments. Kleibergen and Paap rank LM and Cragg-Donald F tests check whether instruments are associated with IVs while Hansen J statistic tests whether IVs are related with errors. . Kleibergen and Paap rank LM and Cragg-Donald F tests results show that the IVs are not serially correlated with lagged value of dependent variable. Therefore, IVs used in these models seem to have valid features. For the critical values of Cragg-Donald Test please look at Stock and Yogo (2002) paper.

\section{References}

AGENOR, P. R., McDermott, C. J., \& Üçer, M. (1997). Fiscal imbalances, capital inflows, and the real exchange rate: the case of Turkey. European Economic Review, 41(3), 819-825.

AKCELIK, Y., Basci, E., Ermisoglu, E., \& Oduncu, A. (2013). The Turkish approach to capital flow volatility. Central Bank of the Republic of Turkey Working Paper, (13/06).

ALPER, K., Kara, H., \& Yörükoğlu, M. (2013). Alternative tools to manage capital flow volatility. BIS Paper, (73z).

ARELLANO, M., \& Bond, S. (1991). Some tests of specification for panel data: Monte Carlo evidence and an application to employment equations. The review of economic studies, 58(2), 277-297.

ARELLANO, M., \& Bover, O. (1995). Another look at the instrumental variable estimation of errorcomponents models. Journal of econometrics, 68(1), 29-51.

AYDIN, B., \& Igan, D. (2012). Bank lending in Turkey: Effects of monetary and fiscal policies. Emerging Markets Finance and Trade, 48(5), 78-104.

AYSAN, A. F., Fendoglu, S., \& Kilinc, M. (2014). Managing short-term capital flows in new central banking: unconventional monetary policy framework in Turkey. Eurasian Economic Review, 4(1), 45-69. 
AYSUN, U. (2012). Capital flows, maturity mismatches, and profitability in emerging markets: evidence from bank level data. The Journal of Developing Areas, 46(1), 211-239.

BALTAGI, B. H. (2008). Forecasting with Panel Data. Journal of Forecasting, 27, p. 153- 173.

BIKKER, J. A., \& Haaf, K. (2002). Competition, concentration and their relationship: An empirical analysis of the banking industry. Journal of Banking \& Finance, 26(11), 2191-2214.

BLUNDELL, R.W. and Bond, S.R. (1998). Initial Conditions and Moment Restrictions in Dynamic Panel Data Models. Journal of Econometrics, 87: 115-143.

BRONER, F., Didier, T., Erce, A., \& Schmukler, S. L. (2013). Gross capital flows: Dynamics and crises. Journal of Monetary Economics, 60(1), 113-133.

BRUNO, V., \& Shin, H. S. (2014). Cross-Border Banking and Global Liquidity ${ }^{\star}$.The Review of Economic Studies, rdu042.

CABALLERO, J. A. (2014). Do surges in international capital inflows influence the likelihood of banking crises?. The Economic Journal. October 2014, p.281-290.

CALVO, G. A., Leiderman, L., \& Reinhart, C. M. (1994). The capital inflows problem: Concepts and issues. Contemporary Economic Policy, 12(3), 54-66.

CALVO, G. A., Leiderman, L., \& Reinhart, C. M. (1996). Inflows of Capital to Developing Countries in the 1990s. The Journal of Economic Perspectives, 123-139.

CBRT, Financial Stability Report, November 2015.

CRAGG, J. G., and Donald, S.G. (1993). Testing identifiability and Specification in Instrumental Variables Models. Econometric Theory, 9: 222-240.

DAVIDSON, R. and MacKinnon, J.G. (1993). Estimation and Inference in Econometrics. Oxford:Oxford University Press.

GREENE, W. H. (2008). Econometric Analysis. Granite Hill Publishers.

HANSEN, L. P. (1982). Large sample properties of generalized method of moments estimators. Econometrica: Journal of the Econometric Society, 1029-1054.

HERRMANN, S., \& Mihaljek, D. (2010). The determinants of cross-border bank flows to emerging markets: new empirical evidence on the spread of financial crises.

KLEIBERGEN, F., \& Paap, R. (2006). Generalized reduced rank tests using the singular value decomposition. Journal of econometrics, 133(1), 97-126.

MENDOZA, E. G., \& Terrones, M. E. (2008). An anatomy of credit booms: evidence from macro aggregates and micro data (No. w14049). National Bureau of Economic Research.

MERCAN, M., Reisman, A., Yolalan, R., \& Emel, A. B. (2003). The effect of scale and mode of ownership on the financial performance of the Turkish banking sector: results of a DEA-based analysis. SocioEconomic Planning Sciences, 37(3), 185-202.

MISHKIN, F. S. (2009). Why we shouldn't turn our backs on financial globalization. IMF Staff Papers, 139-170.

OZSUCA, E. A., \& Akbostanci, E. (2015). An Empirical Analysis of the Risk Taking Channel of Monetary Policy in Turkey. Emerging Markets Finance and Trade, ,1-21.

SCHAFFER, M. E. (2012). xtivreg2: Stata module to perform extended IV/2SLS, GMM and AC/HAC, LIML and k-class regression for panel data models.Statistical Software Components.

STOCK, J. H., \& Yogo, M. (2002). Testıng For Weak Instruments In Linear Iv Regression. National Bureau Of Economic Research, Working Paper No: 284. 
REINHART, C. M., \& Rogoff, K. (2009). This time is different: eight centuries of financial folly. Princeton University Press.

REINHART, C., \& Calvo, G. (2000). When capital inflows come to a sudden stop: Consequences and policy options. , Munich Personal RePEc Archive, 2000, No: 6982.

YENTÜRK, N. (1999). SHORT-TERM CAPITAL INFLOWS AND THEIR IMPACT ON MACROECONOMIC STRUCTURE: TURKEY IN THE 1990s. The Developing Economies, 37(1), 89-113.

WOOLDRIDGE, J. M. (2010). Econometric analysis of cross section and panel data. MIT press. 